\title{
METODE PEMBELAJARAN AL-QUR'AN DI SEKOLAH \\ TAHFIDZ ANAK USIA DINI SAHABAT QUR'AN (TAUD SAQU) JEMBER: KAJIAN LIVING QUR'AN
}

\author{
Abdulloh Dardum \\ Institut Agama Islam Negeri Jember \\ dardumabdullab609@gmail.com \\ Nurul Sa'adah \\ Institut Agama Islam Negeri Jember \\ nurulsaadah778@gmail.com
}

\begin{abstract}
Abstrak
Tradisi menghafal Alquran sudah ada sejak masa Nabi Saw. dan para sahabatnya. Tradisi ini terus berlangsung hingga saat ini. Karena itu banyak berdiri lembaga yang fokus pada tahfir Alquran, baik itu berupa yayasan, pesantren, dan sebagainya dengan metodenya masingmasing. Bahkan ada juga lembaga tahfir, yang dikhususkan untuk mencetak para buffär dari kalangan anak-anak usia dini. Tentu saja bukan perkara mudah untuk mengajar bahkan mencetak anak-anak usia dini menjadi penghafal Alquran. Dalam konteks inilah kajian living qur'an ini ingin mengungkap bagaimana metode yang digunakan oleh Sekolah Tahfidz Anak Usia Dini Sahabat Qur'an (TAUD SAQU) Jember dalam pembelajaran Alquran untuk anak usia dini. Metode yang digunakan dalam penelitian ini adalah metode kualitatif, sedangkan sumber data diperoleh melalui wawancara, observasi, dan dokumentasi. Data yang didapatkan selanjutnya dianalisis, kemudian dilakukan penarikan kesimpulan. Hasil penelitian menunjukkan bahwa ada 3 metode yang digunakan dalam pembelajaran Alquran di TAUD SAQU Jember: 1) Metode Tarbiyah, yaitu materi keagamaan yang diajarkan kepada anak-anak yang mencakup bacaan zikir pagi, doa-doa, asmaul husna, hadis, tauhid, dan sebagainya. 2) Metode Tahaiji, yaitu materi tentang bagaimana mempelajari dan mengeja huruf-huruf hijaiyah dan 3) Metode Tahfiz, yaitu hafalan Alquran dengan menggunakan TTM (Talaqqi-Tasmi'Muräja'ah).
\end{abstract}

Kata Kunci: Living, al-Qur'an, Tabfiz:

\begin{abstract}
The tradition of memorizing the Koran (Alquran) has existed since the time of the Prophet and friends. This tradition continues to this day. Because of that, there are many institutions that focus on the tahfidz of the Koran, both in the form of foundations, Islamic boarding schools, and so on with their respective methods. There is even a tabfidz institute which is devoted to producing buffadz from young children. Of course, it is not an easy matter to teach and even print young children to memorize the Koran. It is in this context that this study of living quran wants to reveal how the methods used by the Tabfidz. Early Childhood School of Sababat
\end{abstract}


An-Nisa' : Jurnal Kajian Perempuan \& Keislaman

Vol. 14, No. 1, April 2021

p-ISSN : $2086-0749$

e-ISSN : 2654-4784

Qur'an (TAUD SAQU) Jember in learning the Koran for early childhood. The method used in this study is a qualitative method, while the data sources were obtained from interviews, observation, and documentation. The data obtained is then analyzed, then conclusions are drawn. The results showed that there were 3 methods used in learning the Koran at TAUD SAQU Jember: 1) Tarbiyah method, which is religious material tanght to children which includes morning dbikr, prayers, asmaul busna, hadis, taubid, and so on . 2) Tahajji method, which is material on how to learn and spell bijaiyah letters and 3) Tabfir method, which is memorizing the Koran by using TTM (Talaqqi-Tasmi'-Muräja'ab).

Keywords: Living, al-Qur'an, Tabfiz: 


\section{Pendahuluan}

Sejak diturunkan empat belas abad yang lalu, umat Islam senantiasa berinteraksi dengan Alquran menggunakan berbagai macam cara. Mulai dari mengimani isi dan kandungannya, membaca dan menghafal ayat-ayatnya, sampai upaya untuk menggali maknanya (tafsir).

Dalam konteks menghafal ayat-ayat Alquran, tradisi ini sudah berjalan sejak masa pewahyuan berlangsung. Saat ayat Alquran diturunkan, di samping Nabi Saw. memerintahkan para sahabat untuk mencatat Alquran, beliau juga memerintahkan mereka untuk menghafalnya. Sejarah mencatat beberapa nama sahabat yang populer sebagai penghafal Alquran, seperti khulafäur rā syidin, Ibn Mas'ud, Ubay bin Ka'ab, dan sebagainya.

Tradisi menghafal ayat-ayat Alquran ini terus berlangsung hingga saat ini. Munculnya para penghafal Alquran dari generasi ke generasi menandakan penjagaan atau pemeliharaan secara tidak langsung dari Allah Swt. terhadap Alquran. Sebagaimana ditegaskan dalam Alquran:

"Sungguh Kamilab yang menurunkan Alquran, dan Kami pula yang benar-benar memelibaranya." (QS. Al-Hijr ayat 9).

Upaya untuk menghafal ayat-ayat Alquran bukanlah perkerjaan yang mudah. Butuh kesabaran, keuletan dan keistikamahan di dalam semua prosesnya, mulai dari menghafal, sampai muräja'ah (mengulang-ulang) untuk menjaga hafalannya agar tidak lupa. Dewasa ini, mulai banyak muncul lembaga yang fokus pada tahfiz. Alquran, baik itu berupa yayasan, pesantren, dan sebagainya dengan metode masing-masing yang tujuan berdirinya adalah untuk memudahkan umat Islam di dalam belajar membaca dan menghafal ayat-ayat Alquran.

Oleh karena banyaknya alternatif metode yang dikembangkan dalam rangka memudahkan dalam menghafal Alquran, pada akhirnya membuat minat masyarakat muslim untuk mempelajari Alquran semakin meningkat. Bahkan keinginan untuk belajar membaca hingga menghafal Alquran pun muncul dari anak-anak usia dini. Ada banyak lembaga yang menyiapkan program tahfiz. Alquran untuk anak-anak usia dini.

Di Jember, salah satu lembaga tersebut adalah Tahfidz Anak Usia Dini Sahabat Qur'an (TAUD SAQU) Jember. Dalam konteks inilah penelitian ini ingin mengungkap bagaimana metode yang digunakan oleh TAUD SAQU Jember dalam pembelajaran Alquran untuk anak usia dini.

Kajian Teori: Sekilas tentang Living Qur'an 
Living Qur'an tersusun dari dua kata, yakni Living dan Qur'an. Living artinya hidup, sedangkan Qur'an adalah firman Allah Swt. yang diturunkan kepada Nabi Muhammad Saw. Rangkaian dua kata tersebut pada akhirnya diartikan dengan "Alquran yang hidup di masyarakat."1

Living Qur'an bisa juga difahami sebagai Qur'an in Everyday Life, artinya bagaimana Alquran dipahami dan disikapi oleh masyarakat muslim dalam kehidupan mereka, baik dalam konteks individu maupun komunitas dalam sebuah masyarakat. Fenomena seperti ini sebenarnya sudah muncul sejak masa Nabi Saw. Sehingga bisa dikatakan, bahwa embrio living Qur'an ini sudah ada sejak masa awal Islam. Sebagaimana diketahui, dalam beberapa riwayat bagaimana Nabi Saw. pernah menyembuhkan penyakit dengan ruqyah menggunakan surah alFatihah dan menolak sihir dengan surah alMu'amwidzatain (al-Falaq dan al-Nas). ${ }^{2}$

Dengan demikian dapat ditarik sebuah benang merah bahwa living Qur'an adalah kajian penelitian ilmiah dalam ranah studi Alquran dan tafsir yang

1 Sahiron Syamsuddin, "Ranah-ranah Penelitian dalam Studi Alquran dan Hadis", dalam Sahiron Syamsuddin, Metode Penelitian Living Qur'an dan Hadis (Yogyakarta: Teras, 2007), xiv.

2 M. Mansyur, "Living Qur'an dalam Lintasan Sejarah Studi Alqur'an", dalam Sahiron Syamsuddin, Metode Penelitian Living Qur'an dan Hadis, 5. memfokuskan pada studi fenomena Alquran di tengah pusaran budaya dan sosial masyarakat. Sebagaimana yang dibahasakan oleh Muhammad Yusuf bahwa living Qur'an tidak bertumpu pada eksistensi tekstualnya, melainkan pada fenomena sosial yang lahir terkait dengan kehadiran Alquran dalam wilayah geografis tertentu dan mungkin masa tertentu pula. ${ }^{3}$

Ada beberapa model interaksi umat Islam dengan Alquran, di antaranya adalah belajar membaca Alquran. Dulu orang belajar membaca Alquran membutuhkan waktu yang sangat lama, bahkan bisa bertahun-tahun. Akhirnya muncul berbagai metode untuk memudahkan proses belajar membaca Alquran, seperti qiräati, iqra', albarqi dan sebagainya.

Setelah belajar membaca Alquran dilakukan, maka model interaksi berikutnya adalah membaca Alquran itu sendiri. Praktik membaca Alquran tentu saja beragam. Ada yang membaca Alquran sendiri-sendiri, ada juga komunitas yang membacanya bersama-sama, misalnya dalam sebuah pengajian yang sudah ditentukan harinya dalam satu minggu. Bahkan surah yang dibaca pun juga berbeda-beda. Ada komunitas pengajian

${ }^{3}$ Muhammad Yusuf, "Pendekatan Sosiologi dalam Penelitian Living Alquran", dalam Sahiron Syamsuddin, Metode Penelitian Living Qur'an dan Hadis, 37. 
yang membaca surah Yasin, surah Kahfi, dan sebagainya. Ada juga yang membaca keseluruhan ayat Alquran yang dikenal dengan istilah khatmul Qur'ān yang diadakan dalam momen tertentu.

Interaksi muslim berikutnya dengan Alquran adalah dalam bentuk menghafalnya. Sejak Alquran pertama kali diturunkan, tentu saja sudah tak terhitung banyaknya para penghafal Alquran. Dewasa ini bahkan sudah banyak lembagalembaga yang didirikan khusus untuk memudahkan umat Islam dalam menghafalkan ayat-ayat Alquran. Di Indonesia, terhitung lebih dari puluhan lembaga atau pesantren tahfiz, yang sudah berdiri. Motivasi menghafal Alquran pun juga semakin meningkat bahkan juga merambah ke anak-anak usia dini. Karenanya banyak kajian akademis yang dilakukan dalam rangka memotret fenomena pengamalan menghafal Alquran ini. Kajiannya biasanya tidak jauh dari motivasi individu di dalam menghafal Alquran, metode yang digunakan dalam menghafal Alquran, dan sebagainya.

\section{Metodologi Penelitian}

Penelitian ini menggunakan metode kualitatif. Dengan alasan karena penelitian ini dilakukan untuk mengetahui, memahami dan mengkaji fenomena tentang apa yang dialami oleh subjek penelitian seperti perilaku, sikap, perkataan, persepsi, motivasi, dan penerapan suatu nilai-nilai tertentu. ${ }^{4}$

Adapun sumber data dalam penelitian ini berupa hasil wawancara secara langsung, pengamatan di lapangan (observasi) dan dokumentasi yang didapat selama observasi. Peneliti langsung berinteraksi, mengamati dan berpastisipasi dengan subjek penelitian di TAUD SAQU Jember yang memiliki kekhasan dalam metode pembelajaran Alquran. Tanpa pengamatan dan partisipasi langsung ke lapangan, maka data yang didapat dan diperoleh akan kurang luas dan dalam sebagaimana seorang yang mengetahui sesuatu melalui tulisan dengan melihat secara langsung tentu berbeda pengetahuan yang didapatnya. Intinya adalah field research ini objek penelitiannya adalah gejala-gejala, peristiwa dan perilaku tindakan yang terjadi pada sekelompok masyarakat. ${ }^{5}$

Selanjutnya, data yang sudah terkumpul akan dianalisis secara mendalam. Analisis data dilakukan melalui dua tahap, yaitu selama proses pengumpulan data di lapangan dan setelah data tersebut terkumpul. ${ }^{6}$ Secara umum analisis data dilakukan dengan langkah; 1) reduksi data;

\footnotetext{
${ }^{4}$ Muhammad Yusuf, "Pendekatan Sosiologi dalam Penelitian Living Alquran”, 37.

${ }^{5}$ Suharsimi Arikunto, Prosedur Penelitian Suatu Pendekatan Praktek (Jakarta: Rineka Cipta, 2013), 121.

6 Sudarsono, Beberapa Pendekatan dalam Penelitian Kualitatif (Yogyakarta: Gajah Mada Press, 1992), 326
} 
2) penyajian data; dan 3) penarikan kesimpulan. $^{7}$

\section{Pembahasan}

\section{Gambaran Objek Penelitian}

\section{Biografi Syekh Abdurrahman Bakr}

Abdelrahman Elsayed Mohammad

Bakr atau yang lebih dikenal di Indonesia dengan sebutan Syekh Abdurrahman, beliau lahir di sebuah daerah bernama Monofiya di Mesir pada tanggal 09 Januari 1956 M. Hingga sekarang beliau masih berkewarganegaraan Mesir walaupun sudah menetap dan tinggal di Madinah alMunawwaroh sejak kurang lebih 8 tahun yang lalu. ${ }^{8}$

Keikhlasan, kecintaan, dan semangat untuk berkhidmat kepada Alquran mendorong beliau untuk menekuni dan menemukan metode baru yang efektif dan efisien dalam belajar membaca Alquran yang baik dan benar sesuai yang diajarkan Rasulullah Saw. kepada para sahabat.

Salah satu karya beliau dalam bidang Alquran adalah metode baca Alquran atTibyan yang saat ini banyak digunakan di banyak Lembaga Pendidikan Alquran baik di dalam maupun di luar negeri. Beliau

\footnotetext{
7 Miles, M. B dan Huberman, A.M, Qualitative Data Analysis (terj). Tjetjep Rohendi Rohidi (Jakarta: UI Press, 1994), 20.

8 Abdelrahman Bakr, At-Tibyan Fii Ta'limi Qira'ati wa Tajwid Al-Qur'an (Bogor: Islamic Canter Wadi Mubarak, 2017), 45.
}

pernah menjabat sebagai Dirjen Pendidikan dan Pengajaran di Mesir. Memiliki beberapa sanad dalam bidang Qiräah alQur'ān dan memiliki lisence dalam bidang Adab dan Tarbiyah.

Syekh Abdurrohman menjalin kerja sama dengan Yayasan Islamic Center Wadi Mubarak untuk mendirikan Lembaga Tibyan Center di lingkungan Wadi Mubarak sebagai pusat pelatihan, pengembangan dan monitoring penerapan metode at-Tibyan untuk Indonesia khususnya dan negara-negara Asia secara umum. Beliau secara rutin berkunjung ke Indonesia dalam setiap tahun untuk melakukan monitoring dan pembinaan.

\section{Sekilas Tentang Yayasan Sahabat Qur'an (YASAQU)}

Yayasan ini berdiri mula-mula karena ada beberapa anak kecil yang ingin belajar tentang agama lebih tepatnya dalam mengenal Tuhannya dengan membaca Alquran. Dari situlah para guru di Wadi Mubarak bersepakat untuk mendidik anakanak kecil itu. Kegiatan ini berjalan sejak tahun 2008 dan lambat laun para guru bersepakat untuk mendirikan Yayasan Sahabat Qur'an sebagai wadah para santri untuk menimba ilmu Alquran. Yayasan ini berdiri sejak tahun itu dan kemudian diresmikan oleh kemenag Bogor pada Tahun 2014. Sejak tahun 2008 hingga 
tahun 2017 Islamic Center Wadi Mubarak sudah meluluskan kurang lebih 300 hafiz. dan hafizah dari usia anak-anak hingga remaja, dan banyak alumninya yang diterima melanjutkan studi di beberapa perguruan tinggi di Timur Tengah.

Dalam rangka memberikan kemudahan fasilitas pendidikan Alquran untuk ummat, maka Islamic Center Wadi Mubarak mendirikan Yayasan Sahabat Qur'an Wadi Mubarak (YASAQU) yang fokus menyediakan program Pendidikan Al-Qur'an. Di antara programnya adalah: ${ }^{9}$

a. Sekolah Tahfizh Anak Usia Dini Sahabat Qur'an (TAUD SAQU)

Istilah TAUD atau Tahfizh Anak Usia Dini pertama kali dikenalkan oleh Islamic Center Wadi Mubarak, sekaligus sebagai perintis sekolah TAUD SAQU di Bogor, Yogyakarta, Jakarta, dan Madura sejak tahun 2014 M. Sudah tercatat lebih dari 30 cabang TAUD di seluruh Indonesia dengan jumlah murid kurang lebih 1000 santri dengan rentang usia 3 sampai 7 tahun yang sedang mengikuti program hafalan 30 Juz dalam masa pendidikan 4 tahun.

\section{b. Pendidikan Guru Tahfizh Anak Usia Dini Sahabat Qur'an (GURU SAQU)}

9 Abdelrahman Bakr, At-Tibyan Fii Ta'limi Qira'ati wa Tajwid Al-Qur'an (Bogor: Islamic Canter Wadi Mubarak, 2017), 82.
Keberhasilan program TAUD SAQU diminati oleh banyak lembaga pendidikan untuk bekerjasama dan membuka cabang, namun tidak sebanding dengan jumlah guru khusus pembimbing hafalan terlatih yang tersedia. Ini melatarbelakangi diselenggarakannya program pendidikan PG TAUD SAQU.

Program pendidikan khusus ini berlangsung selama 3 bulan pendidikan dan 6 bulan praktik diikuti oleh 30-50 peserta pada setiap angkatannya. Angkatan pertama dimulai tanggal 1 April 2016. Alumni program Pendidikan Guru Tahfizh Anak Usia Dini ini disebar di semua cabang yang sudah siap membuka sekolah TAUD SAQU.

\section{c. Pendidikan Imam Masjid - Sahabat Qur'an (IMAM SAQU)}

Program Pendidikan IMAM SAQU adalah program khusus selama 3 bulan untuk memenuhi kebutuhan Imam Masjid yang memiliki hafalan Alquran sekaligus sebagai pembimbing kegiatan Bimbel dan kegiatan keagamaan. Pendidikan ini diikuti oleh 30-50 peserta setiap angkatannya. Angkatan pertama dimulai pada tanggal 15 Januari 2017.

\section{d. Bimbingan Belajar Sahabat Qur'an (BIMBEL SAQU)}

Program ini memberikan layanan bimbingan Alquran kepada semua kalangan masyarakat, mulai dari pelajar SD, SMP, SMA, mahasantri, karyawan/pegawai, Ibu 
Rumah Tangga, bahkan para pensiunan dengan pilihan materi yang beragam seperti (tilawah, tahsin, tahfiz, tafsir, dan tadabbur Alquran), serta pilihan waktu yang fleksibel di luar jam sekolah ataupun jam kerja. ${ }^{10}$

\section{Sekilas Tentang Sekolah TAUD SAQU Jember}

TAUD SAQU Jember adalah salah satu layanan Pendidikan Tahfizh Anak Usia Dini (setara dengan PAUD-TK) pertama di Jember yang menggunakan Metode atTibyan karya Syekh Abdurrohman Bakr yang didirikan oleh Ustazah Shanty Rofianingtyas. Ustazah Shanty lahir di Jember pada tanggal 13 Agustus 1997 M. beliau adalah istri dari Erwin Pandu Pratama dan juga seorang ibu dari Ananda Thowus Dzakwan. Beliau adalah pengelola sekaligus pendiri Sekolah Tahfizh Anak Usia Dini Sahabat Qur'an Jember.

Beliau pernah menimba ilmu di MI al-Hidayah Mangli pada tahun 2004-2010 M., kemudian beliau melanjutkan studinya di Pondok Pesantren Modern Baitul Arqom Balung selama enam tahun ditambah dengan pengabdian sebagai salah satu staf Mabikori di Pondok Pesantren Baitul Arqom selama satu tahun (20102017 M.). Setelah mengenyam pendidikan di Pondok Pesantren Baitul Arqom, beliau

10 Abdelrahman Bakr, At-Tibyan Fii Ta'limi Qira'ati wa Tajwid Al-Qur'an, 83. berkeinginan untuk melanjutkan studi di luar negeri namun pada saat itu beliau belum memiliki hafalan yang mumpuni untuk persyaratan memasuki universitas yang diinginkan, dari situlah beliau mulai tertarik dengan Islamic Center Wadi Mubarak Bogor yang mulanya hanya ingin mengikuti program khusus tahfizhnya saja, namun beliau gagal masuk kualifikasi sehingga memutuskan untuk mengikuti program PG TAUD di Islamic Center Wadi Mubarak selama satu tahun dengan masa pendidikan 3 bulan dan masa praktik selama 6 bulan.

Program pendidikan ini ditujukan untuk melatih peserta menjadi Guru Tahfizh yang mumpuni kemudian disebar ke seluruh cabang TAUD SAQU di seluruh Indonesia. Tidak berhenti di situ, setelah mengikuti program PG TAUD di Islamic Center Wadi Mubarak beliau melanjutkan studinya di LIPIA Jakarta jurusan Ilmu Syariah selama beberapa semester lalu pada tanggal 20 Januari 2019 beliau menikah dan dikaruniai seorang anak laki-laki. Kemudian beliau memilih untuk fokus mendirikan TAUD SAQU di Jember ini.

TAUD SAQU merupakan salah satu layanan Pendidikan di Islamic Center Wadi Mubarak untuk jenjang anak usia dini dengan program unggulan Tahfizul Qur'an 
dan pembiasaan akhlak Qur'ani.

Harapannya, Alquran menjadi nilai utama dalam tumbuh kembang anak usia dini.

Mulanya TAUD SAQU Jember akan didirikan tepat di samping rumah beliau di jalan Kawi, Sumbersari Jember. Namun karena terkendala dengan perizinan akhirnya lembaga ini bertempat di perumahan Bumi Este Muktisari, blok BB 101 (Belakang BLK) RT 001 RW 024 kelurahan Kranjingan, kecamatan Sumbersari, kabupaten Jember.

Sekolah TAUD SAQU dipimpin oleh Ustazah Shanty Rofianingtyas sebagai kepala sekolah yang dan dibantu oleh tenaga pengajar sebanyak 5 orang. Pada saat ini Sekolah TAUD Sahabat Qur'an memiliki peserta didik sebanyak 20 orang.

TAUD SAQU Jember berdiri di bawah naungan Yayasan Dzakwan Islamic Center sejak tanggal 20 Januari 2020 dan yayasan ini mendapat SK perizinan dari KEMENKUMHAM pada tanggal 20 Januari 2021. Dengan semangat dan juga dukungan penuh dari suami, beliau bertekad untuk mendirikan TAUD SAQU Jember dengan sungguh-sungguh sebagai upaya mensyiarkan agama Islam dan juga sebagai wadah untuk terus belajar serta berjihad di jalan Allah.

'Dengan mengajar, kita juga terus belajar. Sekolah TAUD SAQU ini juga merupakan salah satu visi dan misi pernikahan kami, yaitu untuk terus berdakwah di Jalan Allah."11

Sampai saat ini beliau terus berusaha memberikan yang terbaik untuk anak-anak yang belajar di Sekolah Tahfizh Anak Usia Dini. Beliau terus mengevaluasi seluruh kegiatan dan mencari solusi yang tepat untuk kendala-kendala yang terjadi setiap minggunya. ${ }^{12}$

Adapun visi dari TAUD SAQU Jember adalah: "Menjadi lembaga pendidikan tahfizh anak usia dini yang mampu mencetak generasi penghafal AlQur'an dan berakhlak Qur'ani’. Sedangkan misi dari TAUD SAQU Jember adalah sebagai berikut:

1. Menumbuhkan kegemaran dan kebiasaan membaca dan menghafal Al-Qur'an.

2. Membekali amalan praktis harian anak sesuai tuntunan Islam lewat pemahaman dan pengamalan hadis dan zikir harian serta praktik ibadah.

3. Mengentaskan buta huruf Al-Qur'an sejak usia dini.

4. Menanamkan akbläqul karimah dalam berinteraksi dengan orang tua, teman, dan masyarakat.

11 Wawancara dengan Shanty Rofianingtyas (mudirah TAUD SAQU Jember), 09 Februari 2021 di Jln. Kawi No. 20 A Sumbersari, Jember.

12 Wawancara dengan Shanty Rofianingtyas (mudirah TAUD SAQU Jember), 09 Februari 2021, di Jln. Kawi No. 20 A Sumbersari, Jember. 
5. Menggali dan mengembangkan potensi belajar anak melalui pengajaran Al-Qur'an.

6. Membudayakan tradisi belajar islami.

\section{Metode Pembelajaran Al-Qur'an di TAUD SAQU Jember}

Berdasarkan penelitian yang telah dilakukan, ditemukan 3 metode pembelajaran Alquran yang digunakan di TAUD SAQU Jember, sebagai berikut:

\section{a. Metode Tarbiyah}

TAUD SAQU Jember menggunakan metode tarbiyah (Al-Tibyan fi al-Tarbiyah bil Qur'an) sebagai salah satu metode yang disusun oleh syekh Abdurrohman Bakr. Di dalam metode tarbiyah terdapat beberapa materi pembelajaran yang disampaikan untuk murid-murid TAUD, seperti materi tentang akidah, kisah Nabi, zikir, doa-doa, dan sebagainya.

Dalam buku ini, semua materi disampaikan dengan menggunakan bahasa Arab dan di setiap lembarnya menggunakan warna-warna yang menarik sehingga anak-anak tidak merasa bosan untuk membacanya. Ketika ustazah menyampaikan materi, akan dibacakan secara berulang (tikeār) agar anak-anak mudah dalam mengingat. Hal ini sesuai dengan penuturan salah satu ustazah pengajar di TAUD SAQU Jember:
"Di dalam metode ini, ustazah membacakan dan menjelaskan materi yang dipelajari, karena mayoritas anak-anak belum bisa membaca dengan baik."

Berdasarkan hasil observasi yang dilakukan peneliti, metode tarbiyah ini diterapkan di awal memulai pembelajaran. Karena di dalam buku ini terdapat 11 materi, maka mula-mula ustazah pembina akan membacakan 1 pembahasan dalam 1 bab setiap harinya lalu diikuti oleh muridmurid TAUD SAQU. Materi-materi yang ada di dalam metode tarbiyah tersebut antara lain: 1) zikir pagi, 2) doa-doa, 3) asmaul husna, 4) hadit, 5) akidah, 6) adab, 7) tubfatul athfal, 8) tafsir, 9) sejarah, 10) kisah, dan 11) syair huruf hijaiyah.

Adapun penjelasan singkat dari materi yang ada di dalam metode tarbiyah (Al-Tibyān fì al-Tarbiyah bil Qur'ān) berdasarkan hasil temuan di lapangan sebagai berikut:

1) Zikir pagi

Materi zikir pagi ini menjadi sajian pembuka dalam pembelajaran metode tarbiyah. Salah satu contoh bacaan zikir pagi ini adalah:

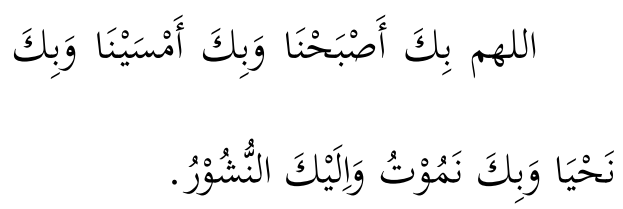


Dalam menyampaikan 1 zikir ini, mula-mula ustazah akan mengenalkan bacaan zikir dengan membaca per kata lalu ditirukan anak-anak sampai mereka hafal, lalu menambah kata lagi sampai tuntas bacaan zikinnya. Penyampaian pembacaan zikir ini sesuai dengan metode hafalan yang diterapkan di TAUD SAQU yakni TTM (Talaqqi-Tasmi'-Murāja'ab) yang akan dibahas dalam penjelasan berikutnya.

2) Doa-doa

Doa-doa yang ada di dalam buku tarbiyah ini adalah doa-doa yang bersumber dari Alquran dan sunnah. Sama seperti yang dijelaskan dalam uraian sebelumya, ustazah akan membacakan secara berulang dan per kata kepada anak-anak TAUD sampai mereka menghafalnya. Contoh bacaan doa di dalam metode tarbiyah ini sebagai berikut:

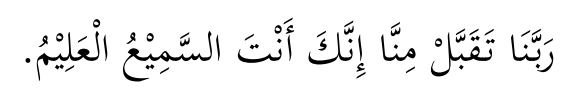

3) Asmaul husna

Materi ini adalah mengenalkan nama-nama Allah kepada anak-anak. Karena materi bacaan menggunakan bahasa Arab, maka ustazah juga menyampaikan makna dari asma-asma Allah yang dipelajari. Contoh bacaan asmaul husna dalam bab ini adalah sebagai berikut:

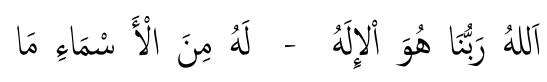

$$
\text { اصْطَفَاى. }
$$

"Allah Tuban kami Dia lah yang patut disembah, Dia yang memiliki nama-nama yang dipilib oleb-Nya."

4) Hadis

Selain mengenalkan kalam-kalam Allah, dalam metode tarbiyah ini juga dikenalkan beberapa hadit yang familier untuk dihafalkan dan diterapkan dalam kehidupan sehari-hari. Berikut contoh salah satu hadis tersebut:

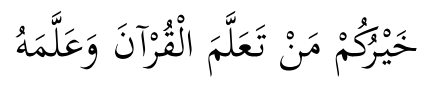

5) Akidah

Anak-anak juga dibekali dengan ilmu tauhid. Berbeda dengan bab-bab sebelumnya, pembelajaran tentang akidah ini ditulis dengan model tanya jawab, contohnya:

$$
\text { لِمَاذَا خَلَقَنَا اللهُ تَعَالَى ؟ }
$$

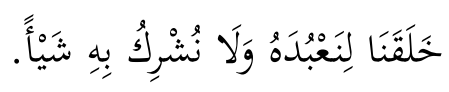

6) Adab

Dalam bab ini, tidak hanya dijelaskan tentang adab-adabnya saja, tetapi juga disertai dengan bacaan doa, seperti adab masuk rumah. Contohnya:

$$
\begin{aligned}
& \text { أَدَابُ دُخُوْْلِ الْمَنْنِلِ }
\end{aligned}
$$

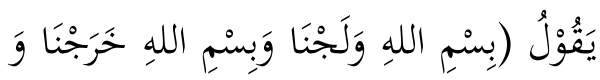

$$
\begin{aligned}
& \text { عَلَى اللهِ رَبِنَّا تَوَكَّلنَّام) }
\end{aligned}
$$


7) Tuhfatul Athfal

Bab ini menjelaskan tentang tajwid dan teorinya. Pada bacaan pertama terdapat muqaddimah yang dibaca, lalu materi tentang hukum tajwid.

8) Tafsir

Pada bab tafsir ini, selama peneliti melakukan observasi belum pernah disampaikan, hal ini dikarenakan kondisi pembelajaran TAUD SAQU Jember yang masih belum aktif seperti biasa.

9) Sejarah

Di dalam bab ini, salah satu bab yang disampaikan adalah kisah tentang nasab Nabi Muhamad Saw., sama seperti di bab akidah yakni disampaikan dengan model tanya jawab sebagai berikut:

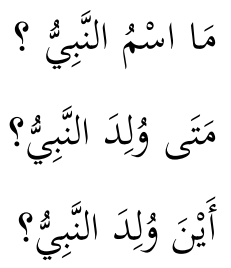

10) Kisah

Kisah yang ada di dalam metode tarbiyah ini diambil dari kisah yang ada di dalam hadis, inilah yang juga membedakan TAUD SAQU dengan sekolah lainnya di mana mayoritas kisah-kisah yang disampaikan untuk anak-anak usia dini diambil dari dongeng-dongeng.

11) Syair huruf hijaiyah

Dalam bab ini, untuk mengenalkan anak-anak tentang huruf hijaiyah terdapat syair yang dilagukan sehingga anak-anak semangat dalam menyanyikannya. Di dalam metode tarbiyah ini, tampak keunikan metode al-Tibyan dengan metode yang lainnya. Sehingga membuat metode ini dirasa cocok untuk kalangan anak-anak, dari konsep penyampaian.

Dapat disimpulkan bahwa penggunaan metode Tarbiyah sebagaimana diuraikan di atas merupakan suatu bentuk pelaksanaan misi TAUD SAQU Jember untuk membekali amalan praktis harian anak sesuai tuntunan Islam lewat pemahaman dan pengamalan hadis dan zikir harian serta praktik ibadah.

\section{b. Metode Tahajji}

Metode tahajji yakni metode belajar membaca Alquran dengan cara mempelajari, serta mengeja huruf-huruf hijaiyyah dan hukum-hukum bacaannya dengan bahasa Arab. Adapun buku panduan yang digunakan dalam pembelajaran ini adalah at-Tibyan fi Itqan Qira'atil Qur'an karya Syekh Abdurrahman Bakr. Karena buku referensi yang digunakan berjudul at-Tibyan, akhirnya pembelajaran baca Alquran dengan metode ini dikenal dengan nama metode at-Tibyan.

Metode at-Tibyan memiliki beberapa kelebihan diantaranya; sosok syekh Abdurrahman Bakr sebagai penggagas metode ini dianggap memiliki kapasitas 
sebab penguasaannya terhadap qiräat sab'ah. Selain itu, contoh-contoh yang ada di dalam buku rujukan ini semuanya diambil dari Alquran. Penyampaian materi dalam buku ini juga dikemas dengan menarik dengan menggunakan warnawarni yang tentu saja menyenangkan bagi anak-anak usia dini. ${ }^{13}$

Dalam konteks ini, Yuni Eko Widayanti menjelaskan bahwa metode atTibyan merupakan metode belajar membaca Alquran yang disampaikan dengan cara mengeja (tahajji), di dalamnya terdapat pembelajaran bahasa Arab, karena dibahas tuntas huruf per huruf dan kaidah tajwidnya melalui pendekatan klasikal serta kebenaran membaca melalui pendekatan individual dengan teknik baca simak. ${ }^{14}$

Berdasarkan observasi peneliti, ada beberapa tahapan yang dilakukan ustazah ketika menghadapi anak didik baru. Pertama, ustazah berusaha untuk dekat dengan anak-anak, agar mereka berminat untuk belajar. salah satu cara yang dilakukan, adalah dengan mengajak mereka menggambar, melihat video tentang hurufhuruf hijaiyah, dan lain-lain. Hal ini sesuai

13 Syaiful Anam dan Azis, "Efektivitas Metode at-Tibyan dalam Pembelajaran Membaca alQur'an Anak Usia Dini di TAUD SAQU NURUSSUNNAH di Kecamatan Tembalang Kota Semarang", Jurnal Komunikasi dan Pendidikan Islam, Vol. 9, Nomor 2 (Desember 2020): 23-24.

14 Yuni Eko Widayanti, Karya Tulis Imiah konsep Pembelajaran Al-Qur'an Dalam Perspektif Metode At-Tibyan,

(Http://Alazharpagendingan.Blogspot.Com/diakse s 14 Februari 2020 jam 19.23 WIB). dengan yang disampaikan oleh Ustazah Mufidah, salah satu ustazah TAUD SAQU Jember:

"Maunya anak kan beda-beda. Jadi bagaimana ustazahnya mendekati. Kadang diajak nonton gambar-gambar huruf hijaiyah, yang penting mau diajak duduk. Dibujuk apapun yang penting mau, jadi kami selalu dituntut untuk sabar dan telaten dalam menghadapi anak-anak." ${ }^{" 15}$

Kedua, pembelajaran Alquran yang pertama kali diberikan ustazah TAUD SAQU Jember kepada anak didik baru yakni dengan cara mengenalkan hurufhuruf hijaiyah kepada mereka dengan beraneka cara, seperti menggambar huruf hijaiyah, serta menyediakan alat peraga berbentuk es krim berwarna-warni yang bertulis huruf hijaiyah. Tujuannya untuk menarik perhatian dan minat belajar anakanak. Proses pembelajarannya dengan cara; ustazah mengenalkan huruf hijaiyah serta menyebutkannya lalu diikuti oleh anakanak. Ketika anak-anak dirasa sudah paham, ustazah memberi tebakan dengan menunjuk anak-anak secara acak menyebutkan atau menebak huruf hijaiyah dengan tujuan untuk menambah daya ingat anak-anak terhadap huruf tersebut.

Setelah anak-anak mampu beradaptasi dengan lingkungan sekolah, ustazah akan mengarahkan pembelajaran

15 Wawancara dengan Mufidah Afdaliah (pengajar TAUD SAQU Jember), 06 Februari 2021 di TAUD SAQU Jember. 
Alquran dengan metode at-Tibyan. Buku yang digunakan dalam proses tahajji adalah At-Tibyan fi Itqan Qira'atil Qur'an jilid 1- 2. ${ }^{16}$

\section{c. Metode Tahfiz}

Ada tiga langkah yang digunakan TAUD SAQU dalam proses menghafal Alquran, sebagai berikut:

\section{1) Talaqqi}

Metode ini bisa dikatakan sebagai metode klasik. Malaikat Jibril ketika diperintahkan untuk menyampaikan wahyu kepada Nabi Saw. menggunakan metode talaqqi ini. Sebagaimana tercatat dalam sejarah bahwa beliau adalah seorang yang ummiy, tidak pandai membaca dan menulis. Karenanya ketika beliau menerima wahyu pertama kali, Jibril menuntunnya untuk membaca surah Al-'Alaq ayat 1 sampai $5 .^{17}$

Metode talaqqi ini juga digunakan di TAUD SAQU Jember. Ustazah membacakan Alquran untuk kemudian diikuti oleh anak-anak. Jadi, satu ayat diulang-ulang, kemudian diikuti oleh anakanak, begitu seterusya. ${ }^{18}$

\section{2) Tasmi'}

Tasmi' artinya memperdengarkan. Dalam konteks ini metode tasmì adalah

16 Wawancara dengan Mufidah Afdaliah (pengajar TAUD SAQU Jember), 06 Februari 2021 di TAUD SAQU Jember.

17 Al-Bukhari, Al-Jami' al-Shahih, Vol. 1 (Beirut: Dar Ibn Katsir, 1987), 4.

18 Wawancara dengan Risma Bashori (pengajar TAUD SAQU Jember), 10 februari 2021 di TAUD SAQU Jember. metode di mana pelajar membaca Alquran sementara pengajar menyimak bacaannya. Penerapannya di TAUD SAQU adalah anak-anak membaca Alquran dan ustazah mendengarkan serta menyimak bacaan mereka dengan teliti. Jika ada kesalahan dalam bacaan, maka ustazah akan membenarkannya, termasuk kesalahan dalam hal pengucapan dan makhärijul hurüfnya.

Selain mereka mendengarkan bacaan dari ustazah sebagaimana dijelaskan dalam metode talaqqi sebelumnya, proses tasmi' di TAUD SAQU Jember juga dilakukan dengan cara; anak-anak mendengarkan bacaan menggunakan audio atau headphone yang telah diisi murottal, biasanya murottal yang dianjurkan adalah murottal Syekh Mishary Rashid.

"Ketika berada di sekolah maupun di rumah, anak-anak menggunakan beadphone untuk mendengarkan murottal yang telah didisplay oleh ustazah. Murottal diisi sesuai capaian hafalan masing-masing anak." ${ }^{19}$

Jadi ketika di rumah, anak-anak mendengarkan surah yang dihafal untuk disetorkan keesokan harinya, semisal anak tersebut hafal surah An-Nas maka headphone-nya di isi dengan murottal surah

19 Wawancara dengan Mufidah Afdaliah (pengajar TAUD SAQU Jember), 06 februari 2021 di TAUD SAQU Jember. 
An-Nas, karenanya, setiap hari ustazah akan memperbarui/meng-update murottal masing-masing anak.

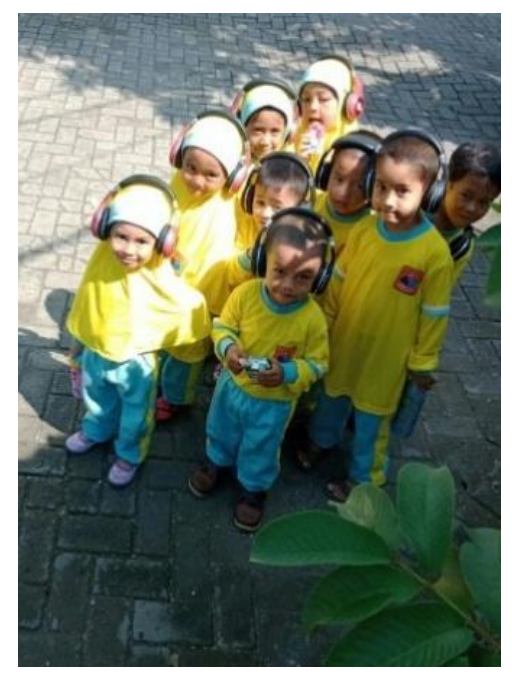

Gambar 1

Kegiatan Anak Didik Menghafal Alquran Menggunakan Headphone.

\section{3) Murāja’ah}

Muräja'ah artinya mengulang-ulang. Metode ini digunakan agar hafalan yang sudah dicapai oleh anak didik tidak lupa. Setiap hari ustazah meminta anak-anak untuk mengulang ayat yang sudah dihafal. Selain itu, untuk menjaga hafalan, di rumah pun juga mereka diminta untuk melakukan muräja'ah. Karena itulah disiapkan buku penghubung antara orang tua dan anak. Sebagai contoh, ketika anak menghafal surah al-Dhuha, maka di buku penghubung tersebut ditulis muräja'ah surah al-Dhuha.

Ada juga murāja'ab bersama, yakni dengan cara muräja'ah surah yang semuanya sudah dihafal. Misalnya, peserata didik yang hafalann terakhirnya adalah surah AlGhasyiyah, maka yang dibaca bersama- sama adalah surah tersebut. Setelah muräja'ah bersama, maka muräja'ah kembali dengan hafalannya sendiri-sendiri, dan satu per satu. ${ }^{20}$

\section{Simpulan}

Dari paparan di atas, dapat disimpulkan bahwa pembelajaran Alquran di TAUD SAQU Jember dilakukan dengan menggunakan 3 metode, yaitu 1) Metode Tarbiyah, di dalam metode ini ada pembelajaran tentang materi keagamaan yang diajarkan kepada anak-anak yang mencakup bacaan zikir pagi, doa-doa, asmaul husna, hadis, tauhid, dan sebagainya. 2) Metode Tahajji, metode ini menjelaskan bagaimana cara mempelajari dan mengeja huruf-huruf hijaiyyah. 3) Metode Tahfiz, metode ini digunakan untuk mencetak calon-calon penghafal Alquran dengan menggunakan langkah TTM (Talaqqi-Tasmi'-Muräja'ah).

\section{Daftar Pustaka}

Al-Bukhari. Al-Jami' al-Shabih. Vol. 1. Beirut: Dar Ibn Katsir, 1987.

Anam, Syaiful dan Azis. "Efektivitas Metode at-Tibyan dalam Pembelajaran Membaca al-Qur'an Anak Usia Dini di TAUD SAQU NURUSSUNNAH di Kecamatan Tembalang Kota Semarang", Jurnal Komunikasi dan Pendidikan Islam, Vol. 9, Nomor 2, Desember 2020.

20 Wawancara dengan Mufidah Afdaliah (pengajar TAUD SAQU Jember), 06 februari 2021 di TAUD SAQU Jember. 
Arikunto, Suharsimi. Prosedur Penelitian Suatu Pendekatan Praktek. Jakarta: Rineka Cipta, 2013.

Bakr, Abdelrahman. At-Tibyan Fii Ta'limi Qira'ati wa Tajwid Al-Qur'an. Bogor: Islamic Canter Wadi Mubarak, 2017. At-Tibyan Fii Itqan al-Qira'at bi Al-Qur'an. Bogor: Islamic Canter Wadi Mubarak, 2017.

Mansur, M. "Living Qur'an dalam Lintasan Sejarah Studi Alqur'an", dalam Sahiron Syamsuddin, Metode Penelitian Living Qur'an dan Hadis, Yogyakarta: Teras, 2007.

Miles, M. B dan Huberman, A.M. Qualitative Data Analysis (terj). Tjetjep Rohendi Rohidi. Jakarta: UI Press, 1994.

Sudarsono. Beberapa Pendekatan dalam Penelitian Kualitatif. Yogyakarta: Gajah Mada Press, 1992.

Syamsuddin, Sahiron. "Ranah-ranah Penelitian dalam Studi Alqur'an dan Hadis", dalam Sahiron Syamsuddin, Metode Penelitian Living Qur'an dan Hadis. Yogyakarta: Teras, 2007.

Widayanti, Yuni Eko. Karya Tulis Ilmiah konsep Pembelajaran Al-Qur'an Dalam Perspektif Metode At-Tibyan, (Http://Alazharpagendingan.Blogsp ot.Com/diakses 14 Februari 2020 jam 19.23 WIB).

Yusuf, Muhammad. "Pendekatan Sosiologi dalam Penelitian Living Alquran", dalam Sahiron Syamsuddin, Metode Penelitian Living Qur'an dan Hadis, Yogyakarta: Teras, 2007. 